\title{
Belliella baltica gen. nov., sp. nov., a novel marine bacterium of the Cytophaga-Flavobacterium- Bacteroides group isolated from surface water of the central Baltic Sea
}

\author{
Ingrid Brettar, ${ }^{1}$ Richard Christen ${ }^{2}$ and Manfred G. Höfle ${ }^{1}$
}

Correspondence

Ingrid Brettar

inb@gbf.de

\author{
${ }^{1}$ GBF - German Research Centre for Biotechnology, Dept Environmental Microbiology, \\ Mascheroder Weg 1, D-38124 Braunschweig, Germany \\ UMR 6543 CNRS and Université Nice Sophia Antipolis, Centre de Biochimie, Parc Valrose, \\ F-06108 Nice, France
}

The Cytophaga-Flavobacterium-Bacteroides (CFB) group is considered to be a bacterial group of special relevance for aquatic environments. In marine and freshwater environments, a high abundance of CFB organisms can occur; they are considered to be of high relevance for the degradation of organic matter, such as complex polysaccharides (Höfle, 1982, 1992; Pinhassi et al., 1999; Cottrell \& Kirchman, 2000). The isolates were obtained from surface water of the central Baltic Sea during the decay of a phytoplankton bloom. CFB organisms have been shown to be major degraders of

Published online ahead of print on 8 August 2003 as DOI 10.1099/ ijs.0.02752-0.

\footnotetext{
Abbreviation: CFB, Cytophaga-Flavobacterium-Bacteroides.

The GenBank/EMBL/DDBJ accession numbers for the 16S rRNA gene sequences of strains $B A 134^{\top}$ and $B A 1$ are AJ564643 and AJ564642, respectively.

A phase-contrast micrograph of cells of strain BA $134^{\top}$ and tables showing the API test results and fatty acid profiles are available as supplementary material in IJSEM Online.
}

organic matter that is derived from phytoplankton; these organisms can therefore be considered to contribute to the degradation of plankton blooms in an aquatic environment such as the Baltic Sea. The view of CFB organisms as catalysts of the decay of phytoplankton blooms is supported by the results of earlier studies that were conducted during a calm summer period, when no decay of phytoplankton occurred. In this study period, no CFB isolates were obtained (Höfle \& Brettar, 1996). Despite the relevance of the CFB group for aquatic environments, there is little information available on the taxonomy of aquatic CFB organisms or their physiological potential. The novel genus described here, of the CFB group or of the phylum 'Bacteroidetes', belongs to the class 'Sphingobacteria' according to the most recent issue of Bergey's Manual of Systematic Bacteriology (Ludwig \& Klenk, 2001). This class comprises three families and a total of 15 genera. Belliella baltica gen. nov., sp. nov. was assigned to the largest family, 'Flexibacteriaceae', which currently comprises 10 genera.

Two strains, $\mathrm{BA} 1$ and $\mathrm{BA} 134^{\mathrm{T}}$, were isolated during a cruise 
on board RV Aranda in September 1998, from surface water $\left(5 \mathrm{~m} ; 15^{\circ} \mathrm{C}\right.$; salinity, $7 \%$; $\left.\mathrm{pH} 8.4\right)$ of two stations of the central Baltic Sea [Gotland Deep (BY 15, $57 \cdot 1920^{\circ} \mathrm{N}$, $\left.20 \cdot 0302^{\circ} \mathrm{E}\right)$ and TEILI1 $\left.\left(59 \cdot 2607^{\circ} \mathrm{N}, 21 \cdot 3002^{\circ} \mathrm{E}\right)\right]_{\text {. All }}$ details on environmental conditions, sampling and isolation procedures are given elsewhere (Brettar \& Rheinheimer, 1992; Brettar \& Höfle, 1993; Höfle \& Brettar, 1995; Brettar et al., 2002). The medium for isolation was ZoBell agar (Oppenheimer \& ZoBell, 1952). The strains grew well on full- and half-strength ZoBell agar and on marine broth or agar 2216 (Difco).

The isolates were tested for a number of key characteristics by using standard procedures (Gerhardt et al., 1994), such as the $\mathrm{KOH}$ string test, cell size and morphology (phasecontrast microscopy) and activities of cytochrome oxidase and catalase $\left(3 \% \mathrm{H}_{2} \mathrm{O}_{2}\right)$. Furthermore, production of indole, growth on $0.5 \%$ yeast extract, nitrate reduction and hydrolysis of aesculin, casein, tyrosine, starch, gelatin and DNA were tested. Chitinase, cellulase and pectinase activities were tested as described by Atlas (1993). Strains were additionally characterized by using the whole testspectrum of the API $50 \mathrm{CH}$, API 20NE, API ZYM (bioMérieux) and Biolog GN2 identification systems at $28^{\circ} \mathrm{C}$. Growth was assessed at $4,10,20,25,30,33$ and $37^{\circ} \mathrm{C}$, at $\mathrm{pH} 6,7,9$ and 10 , and at $0,0 \cdot 8,1 \cdot 5,3,6$ and $10 \% \mathrm{NaCl}$. For these tests, half-strength marine broth 2216 (Difco) was used except for the salinity test, where half-strength, saltfree ZoBell medium was supplemented with the respective amount of sea salt.

Ethanol extracts of cells grown at $21^{\circ} \mathrm{C}$ on half-strength marine agar were examined by spectroscopy to check for pigments and flexirubin, as outlined by Gosink et al. (1998). Briefly, cells were extracted in $95 \%$ ethanol, then spectral analysis was performed at $250-700 \mathrm{~nm}$, before and after alkalinization with $0 \cdot 1$ vol. $0 \cdot 1 \mathrm{M} \mathrm{NaOH}$.

Genomic DNA was prepared from individual colonies as described by Moore et al. (1996). 16S rRNA genes were amplified by PCR (Mullis \& Faloona, 1987) and the products were sequenced directly, as described by Moore et al. (1999).

For phylogenetic analyses, related sequences were selected according to previous phylogenetic analyses of a database of 62000 pre-aligned bacterial 16S rRNA gene sequences and BLAST searches against the latest release of EBI (European Bioinformatics Institute). In a preliminary analysis, 150 sequences were selected according to the results of a BLAST query (100 sequences) and previous analyses (50 sequences). The new sequences were aligned automatically (Abdeddaïm, 1997) and then manually [by using SeaView (Galtier et al., 1996)] against these already aligned sequences. The first set of phylogenetic trees allowed us to select 43 sequences of related cultured bacteria (type species, when available) and uncultured clones that were very closely related to the strains studied. When several sequences were available for a type species, the sequence with the least ambiguities was selected. Phylogenetic trees were then constructed by using three different methods: neighbour-joining (BIONJ), maximum-likelihood and maximum-parsimony. For neighbour-joining analysis, distance matrices were calculated by using Kimura's two-parameter correction. BIONJ was performed according to Gascuel (1997) and maximumlikelihood and maximum-parsimony were from PHYLIP (Phylogeny Inference Package, version 3.573c; distributed by J. Felsenstein, Department of Genetics, UW, Seattle, WA, USA). Because of the loose relationships between the 43 selected sequences, homoplasies and aligning difficulties were detected and domains that corresponded to positions $68-150,190-430,445-803,813-988$ and $1002-1407$ of strain $\mathrm{BA} 134^{\mathrm{T}}$ were selected for phylogenetic analysis. Only these domains were used for the analysis shown in Fig. 1. The phylogenetic trees were drawn by using NJPLOT (Perrière \& Gouy, 1996).

DNA was isolated by chromatography on hydroxyapatite (Cashion et al., 1977). DNA-DNA hybridization was carried out as described by De Ley et al. (1970), with the modifications described by Escara \& Hutton (1980) and Huss et al. (1983), using a Gilford system model 2600 spectrometer. Renaturation rates were calculated with the TRANSFER.BAS program (Jahnke, 1992). The DNA G $+\mathrm{C}$ content (mol\%) of the strains was determined by using HPLC analysis of hydrolysed DNA, according to Tamaoka \& Komagata (1984) and Mesbah et al. (1989).

For cellular fatty acid analysis, strains were grown on halfstrength marine agar 2216 (Difco) for $24 \mathrm{~h}$ at $28^{\circ} \mathrm{C}$. Fatty acid methyl esters were obtained from washed cells by saponification, methylation and extraction. Analysis by GC was controlled by MIS software (Microbial ID) and peaks were integrated and identified automatically by the Microbial Identification software package (Sasser, 1990).

The strains were Gram-negative, tender, straight rods of $0 \cdot 3-0.5 \mu \mathrm{m}$ in width and $0.9-3.0 \mu \mathrm{m}$ in length (Supplementary Fig. A, IJSEM Online). Occasionally, chains of up to six cells were observed. Gliding motility was not observed by phase-contrast microscopy. Colonies were circular, smooth, transparent and pink on half-strength marine agar. With ongoing incubation, colonies became opaque and their colour intensified and changed to orange. In terms of physiological features, the two strains analysed showed comparable responses. The strains were catalase-, cytochrome oxidase- and aminopeptidase-positive. Growth was observed at $4-33^{\circ} \mathrm{C}$ for strain BAl and at $4-37^{\circ} \mathrm{C}$ for strain BA134 ${ }^{\mathrm{T}}$. Both strains showed good growth between 10 and $30^{\circ} \mathrm{C}$, with optimum growth between 20 and $25^{\circ} \mathrm{C}$ for strain BA1 and between 25 and $30^{\circ} \mathrm{C}$ for strain BA134 ${ }^{\mathrm{T}}$. Growth was observed at salinities from 0 to $6 \%$, with good growth between 0 and $3 \%$. Growth occurred at $\mathrm{pH}$ 6-10, with an optimum around neutral conditions. Both strains were able to reduce nitrate to nitrite. They hydrolysed aesculin, starch and DNA. They did not produce indole and did not degrade tyrosine, gelatin or cellulose. No growth occurred on media that contained chitin, pectin or casein. 


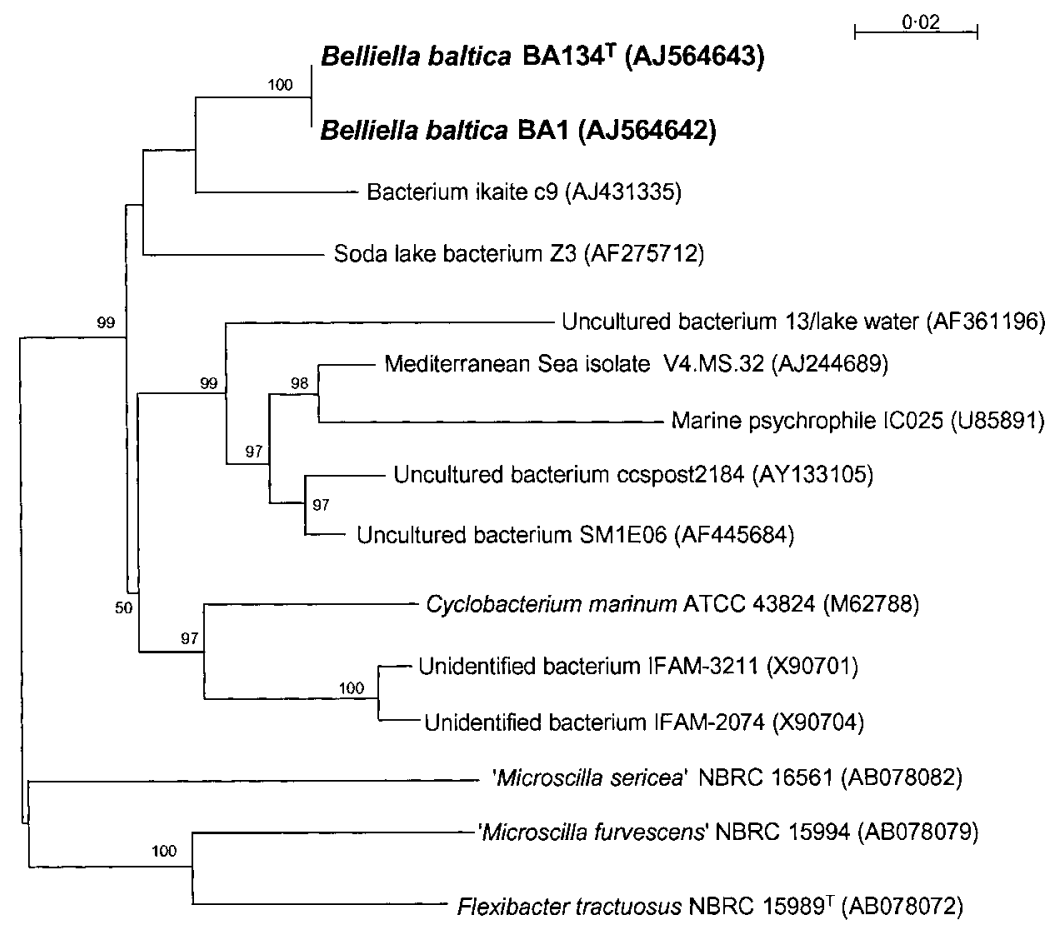

Fig. 1. Unrooted phylogenetic tree resulting from analysis of nearly complete $16 \mathrm{~S}$ rRNA gene sequences. The topology shown was obtained by using the neighbour-joining algorithm. Bootstrap values (\%) are only indicated for branches that were also retrieved by parsimony (a single, most parsimonious tree) and maximum-likelihood $[P<0.01 ; 661$ trees examined; In(likelihood), -814.63698] and therefore define robust clusters. Strains $\mathrm{BA} 134^{\top}$ and $\mathrm{BA} 1$ formed a robust cluster with the alkaliphilic strains Bacterium ikaite c9 and Soda lake bacterium Z3.

In the flexirubin test, the strains did not show a change in colour after alkalinization, either with the $\mathrm{KOH}$ string test or after alkalinization of ethanol extract of cells. The spectrum of the ethanol extract of both strains showed a broad peak with a maximum around $475 \mathrm{~nm}$ and two shoulder peaks at 450 and $505 \mathrm{~nm}$, peaks that are typical for carotinoids. Alkalinization did not show a bathychromatic shift of the peaks. We therefore assume that the strains contained carotinoids but no flexirubins, as often observed for marine CFB organisms (Reichenbach et al., 1981).

Results of the API tests are given in detail in Supplementary Table A in IJSEM Online. In the API 50CH test system, the strains produced acid from a total of 20 substrates, with use of 19 substrates by strain BA1 and 16 substrates by strain $\mathrm{BA} 134^{\mathrm{T}}$. By the API 20NE test, the same six positive reactions were observed for both strains. By the API ZYM test, 11 enzymic activities were detected, with one lacking for strain BA1. In the Biolog GN2 test system, the substrate spectra of the strains differed: strain BA1 used 14 substrates and strain BA134 ${ }^{\mathrm{T}}$ used 22 substrates, with 12 commonly used substrates. As a general rule, phenotypic features were rated as positive when a signal was obtained, either weak or more pronounced.

In terms of phenotypic features, the strains could be differentiated from the most closely related species with a validly published name, Cyclobacterium marinum (Raj \& Maloy, 1990), by cell morphology, salt dependence and tolerance, $\mathrm{pH}$ tolerance, nitrate reduction, hydrolysis of starch and abilities to produce acid from four carbohydrates and to use five carbonic acids (Table 1). Only those phenotypic features that were expressed for both strains were used as differential features, i.e. variable features were not included.

Phylogenetic analysis based on 16 rRNA gene sequences revealed that the two $B$. baltica strains, BA1 and BA134 ${ }^{\mathrm{T}}$, formed a very robust clade (all methods, $100 \%$ of bootstrap replications; Fig. 1). The strains also formed a robust clade with $C$. marinum that was separate from any other described species. The Baltic Sea strains could therefore be recognized as members of the genus Cyclobacterium. On the other hand, the B. baltica strains were very distinct from C. marinum, with a low $16 \mathrm{~S}$ rRNA gene sequence similarity of $90 \cdot 8 \%$ (133 sequence differences). Additionally, bacteria that originated from alkaline environments (e.g. bacterium ikaite c9, Soda lake bacterium Z3) are more closely related to the $B$. baltica strains than $C$. marinum, and form a robust clade.

In terms of $16 \mathrm{~S}$ rRNA gene sequence similarity, strain BA $134^{\mathrm{T}}$ showed a very high similarity of $99.93 \%$ to strain BA1. Sequence similarities with submitted sequences of either strains or clones always showed similarities of $<94 \%$. Highest similarity was found with the CFB group bacterium ikaite c9 (GenBank accession no. AJ431335; 93.6\% 16S rRNA similarity), which was isolated from alkaline ikaite tufa columns in Greenland (Stougaard et al., 2002), and an unidentified bacterium from Hailaer soda lake in China (AF275712; 92.3 \% 16S rRNA similarity). In terms of species with validly published names, highest similarity was found with C. marinum (M62788; 90.8\% 16S rRNA similarity) (Raj \& Maloy, 1990; Woese et al., 1990). All other species of 
Table 1. Differential features of Belliella baltica strains and Cyclobacterium marinum

Taxa: 1, BA1; 2, BA134 ${ }^{\mathrm{T}}$; 3, C. marinum [data from Raj \& Maloy (1990), comprising strains C. marinum $\mathrm{Raj}^{\mathrm{T}}$ (ATCC 25205 ${ }^{\mathrm{T}}$ ), WH-A (ATCC 43824) and WH-B (ATCC 43825)]. Response: +, good response; $\mathrm{W}$, weak response; -, no response.

\begin{tabular}{|c|c|c|c|}
\hline Feature & 1 & 2 & 3 \\
\hline Cell morphology & Rods, straight & Rods, straight & Vibroid, ringlike, spiral, coils \\
\hline Cell size $(\mu \mathrm{m})$ & $0 \cdot 4-0 \cdot 5 \times 0 \cdot 9-2 \cdot 2$ & $0 \cdot 3-0 \cdot 4 \times 1 \cdot 5-3 \cdot 0$ & $0 \cdot 3-0 \cdot 7 \times 0 \cdot 8-1 \cdot 5$ \\
\hline Colony colour & Pink/orange & Pink/orange & Pink \\
\hline $\mathrm{G}+\mathrm{C}$ content $(\mathrm{mol} \%)$ & $35 \cdot 5$ & $35 \cdot 3$ & $34-38$ \\
\hline \multicolumn{4}{|l|}{ Salinity $(\%)$ : } \\
\hline Growth range & $0-6$ & $0-6$ & $1 \cdot 5-15$ \\
\hline Optimum & $0-3 \cdot 4$ & $0-3 \cdot 4$ & $1 \cdot 5-5$ \\
\hline \multicolumn{4}{|l|}{ Temperature $\left({ }^{\circ} \mathrm{C}\right)$ : } \\
\hline Growth range & $4-33$ & $4-37$ & $4-40$ \\
\hline Optimum & $20-25$ & $25-30$ & 25 \\
\hline $\mathrm{pH}$ growth range & $6-10$ & $6-10$ & $6-9$ \\
\hline Nitrate reduction to nitrite & + & + & - \\
\hline Hydrolysis of starch & + & + & - \\
\hline \multicolumn{4}{|l|}{ Acid production from: } \\
\hline D-Mannose & - & - & + \\
\hline Rhamnose & - & - & + \\
\hline Methyl $\alpha$-D-glucoside & - & - & + \\
\hline Cellobiose & $\mathrm{W}$ & + & - \\
\hline \multicolumn{4}{|l|}{ Utilization of: } \\
\hline Malate & - & - & + \\
\hline Citric acid & - & - & + \\
\hline D-Gluconic acid & - & - & + \\
\hline Malonic acid & - & - & + \\
\hline Succinic acid & - & - & + \\
\hline
\end{tabular}

the 'Flexibacteriaceae' with validly published names were related more distantly and showed $16 \mathrm{~S}$ rRNA gene sequence similarities of $<89 \%$.

DNA-DNA hybridization between strains BA134 ${ }^{\mathrm{T}}$ and BA1 ranged from $72 \cdot 9$ to $76 \cdot 0 \%$. According to Wayne et al. (1987), the DNA relatedness of the strains is thus still $>70 \%$, which is considered to be the lower limit for members of the same species. Based on DNA binding data and the high 16S rRNA gene sequence similarity of $99.93 \%$, we suggest that the two strains are members of the same species.

The DNA G $+\mathrm{C}$ contents of strains BA134 ${ }^{\mathrm{T}}$ and BA1 were 35.3 and $35.5 \mathrm{~mol} \%$, respectively (Table 1 ). The $\mathrm{G}+\mathrm{C}$ contents of the related species $C$. marinum ranged from 34 to $38 \mathrm{~mol} \%$ (Raj \& Maloy, 1990; Gosink et al., 1998) and are therefore within the same range as the strains of $B$. baltica described here.

Predominant fatty acids of the B. baltica strains were iso- $\mathrm{C}_{15: 0}(18 \cdot 9-22 \cdot 5 \%)$, iso- $\mathrm{C}_{15: 0} \mathrm{G}(10 \cdot 1-10 \cdot 3 \%)$, iso$\mathrm{C}_{17: 1} \omega 9 c \quad(6 \cdot 6-10 \cdot 2 \%), \mathrm{C}_{16: 1} \omega 7 c(7 \cdot 1-11 \cdot 45 \%)$ and $\mathrm{C}_{17: 1} \omega 6 c(4 \cdot 8-9 \cdot 8 \%$ ) (for details see Supplementary Table B, IJSEM Online). Fatty acids of minor contribution (1-5\% of total fatty acids) were $\mathrm{C}_{13: 1}$ (at 12-13), iso- $\mathrm{C}_{14: 0}$,
$\mathrm{C}_{15: 0}$, anteiso- $\mathrm{C}_{15: 0}$, iso- $\mathrm{C}_{15: 0} 3-\mathrm{OH}, \mathrm{C}_{15: 1} \omega 6 c$, iso- $\mathrm{C}_{16: 0}$, iso- $\mathrm{C}_{16: 0} 3-\mathrm{OH}$, iso- $\mathrm{C}_{16: 1} \mathrm{H}, \mathrm{C}_{16: 1} \omega 5 c$, iso- $\mathrm{C}_{17: 0} 3-\mathrm{OH}$, anteiso- $\mathrm{C}_{17: 1} \mathrm{~B}, \mathrm{C}_{17: 1} \omega 6 c$ and $\mathrm{C}_{17: 1} \omega 8 c$. The cellular fatty acid composition of the $B$. baltica strains was dominated by branched-chain fatty acids, which formed $70 \%$ of the total. This calculation is based on the assumption that the detected double peak (equivalent chain length, 15·19$15 \cdot 48$ ) represents $C_{16: 1} \omega 7 c$, which cannot be differentiated from iso- $\mathrm{C}_{15: 0} 2-\mathrm{OH}$ by the MIDI system. Otherwise, the fraction of iso-branching fatty acids would be even higher. Comparison of the B. baltica strains with C. marinum $\mathrm{Raj}^{\mathrm{T}}$ (Urakami \& Komagata, 1986) showed, for both species, a high fraction of iso-branched $\mathrm{C}_{15: 0}$ fatty acids, but contrasted with respect to the high content of anteiso- $\mathrm{C}_{15: 0}$ for C. marinum (C. marinum, $31.5 \%$; B. baltica, $4 \cdot 5 \%$ ).

Of species with validly published names, strains BA1 and BA $134^{\mathrm{T}}$ are most closely related phylogenetically to $C$. marinum (Fig. 1). Phylogenetic analyses based on $16 \mathrm{~S}$ rRNA gene sequences revealed, furthermore, that some alkaliphilic strains are affiliated more closely to the B. baltica strains than C. marinum. As for ikaite and soda lakes, the surface water of the Baltic Sea with its phytoplankton bloom can be regarded as an occasionally alkaline environment ( $\mathrm{pH} 8 \cdot 4$, with higher $\mathrm{pH}$ values in the vicinity of algal cells) 
due to alkalinization caused by $\mathrm{HCO}_{3}^{-}$- and/or $\mathrm{NO}_{3}^{-}$uptake by algae (Giraldez et al., 1998; Ullrich et al., 1998). Due to the phylogenetic distance, the Baltic Sea strains were regarded as members of a different genus from C. marinum. These phylogenetic conclusions are furthermore supported by the fatty acid profiles, cell morphology and physiological features. Physiological features that differentiate the Baltic Sea strains from $C$. marinum are $\mathrm{NaCl}$ dependence for growth, salinity and $\mathrm{pH}$ ranges for growth, reduction of nitrate and spectrum of substrates utilized for growth and acid production. A major difference of the cellular fatty acids was the high content of anteiso- $\mathrm{C}_{15: 0}$, which was almost an order of magnitude higher for C. marinum than for $B$. baltica. Based on the results of this polyphasic approach for the novel Baltic Sea isolates, we propose a novel genus and species, Belliella baltica gen. nov., sp. nov. Strain BA $134^{\mathrm{T}}$ is proposed as the type strain of this novel species. The two strains described are considered to belong to the novel species $B$. baltica based on DNA-DNA similarity, 16S rRNA gene sequence comparison, fatty acid composition and phenotypic traits.

\section{Description of Belliella gen. nov.}

Belliella [Bel.li.el'la. N.L. fem. n. Belliella after the late aquatic microbiologist Russell Bell, University of Uppsala, in recognition of his work on aquatic bacteria (Bell et al., 1983)].

Cells are Gram-negative, rod-shaped and oxidase- and catalase-positive. Growth is heterotrophic, aerobic and chemoheterotrophic. Predominant fatty acids are iso- $C_{15: 0}$, iso- $\mathrm{C}_{17: 1} \omega 9 c$ and $\mathrm{C}_{17: 1} \omega 6 c$. Cells contain carotinoids, but no flexirubin. $\mathrm{NaCl}$ is not needed for growth, but good growth occurs at up to $3 \% \mathrm{NaCl}$. The genus Belliella belongs to the class 'Sphingobacteria' and the family 'Flexibacteriaceae'. The type species is Belliella baltica.

\section{Description of Belliella baltica sp. nov.}

Belliella baltica (bal'ti.ca. M.L. fem. adj. baltica from the Baltic Sea, referring to the source of the type strain).

Colonies are circular, smooth, convex and entire; they are pink and transparent when young, but become orange and opaque with ongoing incubation $\left(>2\right.$ weeks at $20^{\circ} \mathrm{C}$ on half-strength marine agar). Cells are Gram-negative, rodshaped (width, $0.3-0.5 \mu \mathrm{m}$; length, $0.9-3.0 \mu \mathrm{m}$ ) and oxidase- and catalase-positive. Nitrate is reduced to nitrite. Temperature for growth is $4-37^{\circ} \mathrm{C}$, with an optimum around $25^{\circ} \mathrm{C} . \mathrm{NaCl}$ is not needed for growth; strains are tolerant of salinities up to $6 \%$, with optimal growth between 0 and $3 \%$. Strains grow at $\mathrm{pH} 6-10$, with an optimum around neutral $\mathrm{pH}$. Growth occurs on $0.5 \%$ yeast extract; aesculin, starch and DNA are hydrolysed. Acid is produced from L-arabinose, D-xylose, galactose, D-glucose, D-fructose, aesculin, salicin, cellobiose, maltose, lactose, melibiose, sucrose, trehalose, D-raffinose and starch. The following enzymic activities are present: $\alpha$ - and $\beta$-glucosidases, $\beta$-galactosidase, acidic and alkaline phosphatases, lipase (C8), leucine, valine and cystine arylamidases, trypsin, chymotrypsin and naphthol phosphohydrolase. Glucose, arabinose and maltose are assimilated. D-Galactose, gentobiose, $\alpha$-D-glucose, $\alpha$-D-lactose, lactulose, maltose, Dtrehalose, acetic acid, $\alpha$-ketobutyric/glutaric/valeric acids and L-glutamic acid are utilized as substrates. DNA G $+\mathrm{C}$ content of the type strain is $35 \cdot 4 \mathrm{~mol} \%$.

The type strain is BA134 ${ }^{\mathrm{T}}\left(=\mathrm{DSM} 15883^{\mathrm{T}}=\mathrm{LMG} 21964^{\mathrm{T}}=\right.$ CIP $\left.108006^{\mathrm{T}}\right)$. Of marine or estuarine origin.

\section{Acknowledgements}

This paper is dedicated to the late aquatic microbiologist Russell Bell from the University of Uppsala, Sweden. We greatly acknowledge him as a scientist and friend. J. Bötel is acknowledged for excellent technical assistance. Support by the scientific and technical crew of RV Aranda in September 1998 is greatly acknowledged. Special thanks to H. Kuosa and J. Kupparinen for support with sampling and the cruise. The analytical services by the DSMZ (Deutsche Sammlung für Mikroorganismen und Zellkulturen, Braunschweig, Germany) are greatly acknowledged. Many thanks to S. Verbarg, R. M. Kroppenstedt, P. Schumann and their staff. Many thanks for the excellent support by A. Frühling. This work was part of the EU project 'Marine Bacterial Genes and Isolates as Sources for novel Biotechnological Products' (MARGENES). The project was funded by the Marine Science and Technology (MAST III) programme of the European Commission (contract no. MAS3-CT97-0125).

\section{References}

Abdeddaïm, S. (1997). Fast and sound two-step algorithms for multiple alignment of nucleic sequences. Int J Artif Intell Tools 6, 179-192.

Atlas, R. M. (1993). Handbook of Microbiological Media. Edited by L. C. Parks. Boca Raton, FL: CRC Press.

Bell, R. T., Ahlgren, G. M. \& Ahlgren, I. (1983). Estimating bacterioplankton production by measuring $\left({ }^{3} \mathrm{H}\right)$ thymidine incorporation in a eutrophic Swedish lake. Appl Environ Microbiol 45, 1709-1721.

Brettar, I. \& Höfle, M. G. (1993). Nitrous oxide producing heterotrophic bacteria from the water column of the central Baltic: abundance and molecular identification. Mar Ecol Prog Ser 94, 253-265.

Brettar, I. \& Rheinheimer, G. (1992). Influence of carbon availability on denitrification in the water column of the central Baltic Sea. Limnol Oceanogr 37, 1146-1163.

Brettar, I., Christen, R. \& Höfle, M. G. (2002). Rheinheimera baltica gen. nov., sp. nov., a blue-coloured bacterium isolated from the central Baltic Sea. Int J Syst Evol Microbiol 52, 1851-1857.

Cashion, P., Holder-Franklin, M. A., McCully, J. \& Franklin, M. (1977). A rapid method for the base ratio determination of bacterial DNA. Anal Biochem 81, 461-466.

Cottrell, M. T. \& Kirchman, D. L. (2000). Community composition of marine bacterioplankton determined by $16 \mathrm{~S}$ rRNA gene clone libraries and fluorescence in situ hybridization. Appl Environ Microbiol 66, 5116-5122.

De Ley, J., Cattoir, H. \& Reynaerts, A. (1970). The quantitative measurement of DNA hybridization from renaturation rates. Eur J Biochem 12, 133-142. 
Escara, J. F. \& Hutton, J. R. (1980). Thermal stability and renaturation of DNA in dimethyl sulfoxide solutions: acceleration of the renaturation rate. Biopolymers 19, 1315-1327.

Galtier, N., Gouy, M. \& Gautier, C. (1996). SeaView and Phylo_win, two graphic tools for sequence alignment and molecular phylogeny. Comput Appl Biosci 12, 543-548.

Gascuel, O. (1997). BIONJ: an improved version of the NJ algorithm based on a simple model of sequence data. Mol Biol Evol 14, 685-695.

Gerhardt, P., Murray, R. G. E., Wood, W. A. \& Krieg, N. R. (editors) (1994). Methods for General and Molecular Bacteriology. Washington, DC: American Society for Microbiology.

Giraldez, N., Aparicio, P. J. \& Quiñones, M. A. (1998). Blue light requirement for $\mathrm{HCO}_{3}^{-}$uptake and its action spectrum in Monoraphidium braunii. Photochem Photobiol 68, 420-426.

Gosink, J. J., Woese, C. R. \& Staley, J. T. (1998). Polaribacter gen. nov., with three new species, $P$. irgensii sp. nov., $P$. franzmannii sp. nov. and $P$. filamentus sp. nov., gas vacuolate polar marine bacteria of the Cytophaga-Flavobacterium-Bacteroides group and reclassification of 'Flectobacillus glomeratus' as Polaribacter glomeratus comb. nov. Int J Syst Bacteriol 48, 223-235.

Höfle, M. G. (1982). Glucose uptake of Cytophaga johnsonae studied in batch and chemostat culture. Arch Microbiol 133, 289-294.

Höfle, M. G. (1992). Bacterioplankton community structure and dynamics after large-scale release of nonindigenous bacteria as revealed by low-molecular-weight-RNA analysis. Appl Environ Microbiol 58, 3387-3394.

Höfle, M. G. \& Brettar, I. (1995). Taxonomic diversity and metabolic activity of microbial communities in the water column of the central Baltic Sea. Limnol Oceanogr 40, 868-874.

Höfle, M. G. \& Brettar, I. (1996). Genotyping of heterotrophic bacteria from the central Baltic Sea by use of low-molecular-weight RNA profiles. Appl Environ Microbiol 62, 1383-1390.

Huss, V. A. R., Festl, H. \& Schleifer, K.-H. (1983). Studies on the spectrophotometric determination of DNA hybridization from renaturation rates. Syst Appl Microbiol 4, 184-192.

Jahnke, K.-D. (1992). Basic computer program for evaluation of spectroscopic DNA renaturation data from GILFORD system 2600 spectrometer on a PC/XT/AT type personal computer. J Microbiol Methods 15, 61-73.

Ludwig, W. \& Klenk, H.-P. (2001). Overview: a phylogenetic backbone and taxonomic framework for procaryotic systematics. In Bergey's Manual of Systematic Bacteriology, 2nd edn, pp. 49-65. Edited by D. R. Boone \& R. W. Castenholz. New York: Springer.

Mesbah, M., Premachandran, U. \& Whitman, W. B. (1989). Precise measurement of the $\mathrm{G}+\mathrm{C}$ content of deoxyribonucleic acid by high-performance liquid chromatography. Int J Syst Bacteriol 39, 159-167.

Moore, E. R. B., Mau, M., Arnscheidt, A., Böttger, E. C., Hutson, R. A., Collins, M. D., van de Peer, Y., de Wachter, R. \& Timmis, K. N. (1996). The determination and comparison of the 16S rRNA gene sequences of species of the genus Pseudomonas (sensu stricto) and estimation of the natural intrageneric relationships. Syst Appl Microbiol 19, 478-492.

Moore, E. R. B., Arnscheidt, A., Krüger, A., Strömpl, C. \& Mau, M. (1999). Simplified protocols for the preparation of genomic DNA from bacterial cultures. In Molecular Microbial Ecology Manual, 1.6.1, pp. 1-15. Edited by A. D. L. Akkermans, J. D. van Elsas \& F. J. de Bruijn. Dordrecht, the Netherlands: Kluwer Academic Press.

Mullis, K. B. \& Faloona, F. A. (1987). Specific synthesis of DNA in vitro via a polymerase-catalyzed chain reaction. Methods Enzymol 155, 335-350.

Oppenheimer, C. H. \& ZoBell, C. E. (1952). The growth and viability of sixty-three species of marine bacteria as influenced by hydrostatic pressure. J Mar Res 11, 10-18.

Perrière, G. \& Gouy, M. (1996). WWW-Query: an on-line retrieval system for biological sequence banks. Biochimie 78, 364-369.

Pinhassi, J., Azam, F., Hemphälä, J., Long, R. A., Martinez, J., Zweifel, U. L. \& Hagström, Å. (1999). Coupling between bacterioplankton species composition, population dynamics, and organic matter degradation. Aquat Microb Ecol 17, 13-26.

Raj, H. D. \& Maloy, S. R. (1990). Proposal of Cyclobacterium marinum gen. nov., comb. nov. for a marine bacterium previously assigned to the genus Flectobacillus. Int J Syst Bacteriol 40, 337-347. Reichenbach, H., Kohl, W. \& Achenbach, H. (1981). The flexirubin pigments, chemosystematically useful compounds. In The Flavobacterium-Cytophaga Group, pp. 101-108. Edited by H. Reichenbach \& O. B. Weeks. Weinheim, Germany: Verlag Chemie.

Sasser, M. (1990). Identification of Bacteria by Gas Chromatography of Cellular Fatty Acids (technical note no. 101). Newark, DE: MIDI Inc. (http://www.midi-inc.com/media/pdfs/TechNote_101.pdf).

Stougaard, P., Jørgensen, F., Johnsen, M. G. \& Hansen, O. C. (2002). Microbial diversity in ikaite tufa columns: an alkaline, cold ecological niche in Greenland. Environ Microbiol 4, 487-493.

Tamaoka, J. \& Komagata, K. (1984). Determination of DNA base composition by reverse-phase high-performance liquid chromatography. FEMS Microbiol Lett 25, 125-128.

Ullrich, W. R., Lazarova, J., Ullrich, C. I., Witt, F. G. \& Aparicio, P. J. (1998). Nitrate uptake and extracellular alkalinization by the green alga Hydrodictyon reticulatum in blue and red light. J Exp Bot 49, $1157-1162$.

Urakami, T. \& Komagata, K. (1986). Methanol-utilizing Ancylobacter strains and comparison of their cellular fatty acid compositions and quinone systems with those of Spirosoma, Flectobacillus, and Runella species. Int J Syst Bacteriol 36, 415-421.

Wayne, L. G., Brenner, D. J., Colwell, R. R. \& 9 other authors (1987). International Committee on Systematic Bacteriology. Report of the ad hoc committee on reconciliation of approaches to bacterial systematics. Int J Syst Bacteriol 37, 463-464.

Woese, C. R., Maloy, S., Mandelco, L. \& Raj, H. D. (1990). Phylogenetic placement of the Spirosomaceae. Syst Appl Microbiol 13, 19-23. 